\title{
PUSIAU PROFESIONALIŲ RANKININKIUU PARENGTUMO RODIKLIŲ RYŠYS PARENGIAMOJO LAIKOTARPIO PRADŽIOJE
}

\author{
Gintarė Onusaitytė, Antanas Skarbalius \\ Lietuvos kūno kultūros akademija, Kaunas, Lietuva
}

\begin{abstract}
Gintarẻ Onusaitytė. Edukologijos magistrè. Lietuvos kūno kultūros akademijos doktorantė. Mokslinių tyrimų kryptis — sportininkų treni-
\end{abstract} ravimo technologijos.

\begin{abstract}
SANTRAUKA
Tikslas - nustatyti pusiau profesionaliu rankininkiu (PPR) parengtuma ir parengtumo rodikliu tarpusavio priklausomybès ypatumus pradedant sportini sezonq. Buvo nustatyti totaliniai rodikliai ir kūno masès komponentai, atletinis (aerobinè ir anaerobine ištvermè, koju raumenu galingumas, vikrumas, judesiu dažnumas), techninis (kamuolio metimo greitis, kamuolio metimas i toli, kamuolio gaudymas ir perdavimas, kamuolio varymas) parengtumas.

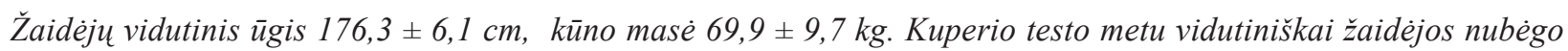
$2,3 \pm 0,19 \mathrm{~km}$, netiesiogiai pagal ši testa vertinta $V O_{2 \max }$ didžiausia reikšmé buvo $56,2 \mathrm{ml} / \mathrm{kg} / \mathrm{min}$, mažiausia $38,6 \mathrm{ml} / \mathrm{kg} / \mathrm{min}$. Atlikdamos Yo-Yo nutrūkstamo intensyvumo ištvermès ir atsigavimo testus žaidejos vidutiniškai nubègo atitinkamai $1593 \pm 566$ ir $554 \pm 204$ metrus. Žaideju laktato koncentracija kraujyje po testu vidutiniškai buvo 10,4 2,8 ir 13,8 2,7 mmol / l atitinkamai. Atlikdamos jégos greitumo šuolius žaidejos vidutiniškai pašoko — $28,2 \pm 2,9 \mathrm{~cm}$ (be ranku mosto) ir 35,4 $\pm 3,5 \mathrm{~cm}$ (su ranku mostu), greitumo jègos atitinkamai $-30,2 \pm 2,7 \mathrm{ir} 36,6 \pm$ $3,4 \mathrm{~cm}$. Didžiausias kamuolio metimo greitis nustatytas tiriamosioms metant i vartus pašokus (71,9 \pm 7,4 km / h), mažiausias — kai metama nuo 7 metru linijos $(66,1 \pm 6,4 \mathrm{~km} / \mathrm{h})$, rankujudesiu dažnumas buvo žemas. Lyginant su kitu šaliu rankininkemis, nustatyti tokie parengtumo ypatumai: PPR jègos greitumo rodikliai yra geresni nei Norvegijos rankininkiu; aerobiné ištvermé blogesnè nei Lenkijos rankininkiu. Nustatyti tokie sqveikos ypatumai: glaudus kūno masès ryšys su koju galingumu $(r=0,40-0,60)$ ir koju galingumo su judesiu dažnumu $(r=0,55-0,59)$. Taip pat nustatytas glaudus ryšys tarp kamuolio metimo greičio ir kamuolio metimo ì tolik $(r=0,78)$.

Nustatyti pusiau profesionaliu vidutinio meistriškumo rankininkiu parengtumo rodikliai, ju ryšys turi teorinę ir praktinę reikšmę apibūdinant žaideju parengtumo lygi ir sudaro prielaidas parengti parengiamojo laikotarpio treniravimo programa. Remiantis C. Carling ir bendraautoriu (2009) teiginiais, judamieji gebejimai tarpusavyje nepriklausomi, bet visi kartu labai reikšmingi. Todèl parengiamuoju laikotarpiu rankininkèms rekomenduotina: lavinti ištvermę, jèga, kartu padidinant rankininkiu aktyviaja kūno masę, kurios dèka pagerètu koju raumenu galingumas; gerinti ranku ir koju judesiu dažnuma, kurie yra labai reikšmingi atliekant veiksmus ginantis ir puolant. Tolesni pusiau profesionaliu rankininkiu treniravimo programu tyrimai leistu ne tik nustatyti ju poveiki parengtumo rodikliu kaitai, bet ir optimizuoti rengima.
\end{abstract}

Raktažodžiai: moteru rankinis, atletinis ir techninis parengtumas, testavimai.

\section{IVADAS}

iuolaikinis moterų rankinis labai dinamiškas (Grünanger, Konig, 2005), iš žaideju reikalauja didelių fizinių pastangu ir išskirtinio rankininkių parengtumo, didelę reikšmę turi ir rankininkių kūno sudejjimas (ūgis, kūno masè) (Hatzimanouil et al., 2005; Bayios et al., 2006; Hasan et al., 2007). D. Hatzimanouil su bendraautoriais (2005) nustatè, kad geresnio kūno sudejjimo (ūgio, mažesnio riebalų kiekio ir didesnès raumenų masės) rankininkių atletinis parengtumas taip pat geresnis.

Žaisdamos rankininkès nuolat patiria fizini kontaktą su varžovu (Gorostiaga et al., 2005). Rungtyniavimo metu žaidejos atlieka mažos trukmès didžiausių pastangų (šuolių, pagreitėjimų, keičiant judejimo kryptị ir gausybę ivvairių tech- 
nikos veiksmų, atsižvelgiant ị taktikos situacijas, reikalaujančias dideliu psichiniu pastangų) veiksmus (Taborsky, 2001; Hasan et al., 2007). Kartu atliekami ir mažesnio intensyvumo vidutinès trukmès (keli pagreitejjimai kontratakuojant ir ginantis nuo varžovų kontratakų) veiksmai. Todèl norint per visas rungtynes išlaikyti didelę sparta - būtinas geras aerobinis ir anaerobinis organizmo parengtumas (Loftin et al., 1996; Hasan et al., 2007).

Rankinio žaidimo kokybẻ priklauso nuo atletinio parengtumo (Gorostiaga et al., 2005; Wallace, Cardinale, 1997; Oxyzoglou, 2008). Jèga ir raumenu galingumas, taip pat kaip ir aerobinis pajègumas, svarbūs žaidžiant rankini ir siekiant pergalès. Kamuolio metimo greitis ir tikslumas yra vieni iš svarbiausių veiksnių, kurie turi lemiamą poveiki pelnant îvarti — greičiau ir tiksliau išmetus kamuolị gali būti pasiektas ịvartis, vartininkei ir gynejjoms nespejus pasirengti ji atmušti (Muijtjens et al., 1991). Žaidžiant rankini, kiekvienos pozicijos žaidejos parengtumo rodikliai yra skirtingi (Oxyzoglou, 2008). Vikrumas, gera pusiausvyra, tikslumas judant su kamuoliu ir be jo, orientacija, geras erdvès bei laiko suvokimas, greitumas ir kojų raumenų galingumas, staigioji jẻga, jègos greitumas yra vieni iš svarbiausių gebėjimų, būtinu kiekvienos pozicijos žaidejjai tiek ginantis, tiek atakuojant vartus (Oxyzoglou, 2008).

Todèl svarbu nustatyti treniruojamos rankinio komandos parengtuma, tikslinga ji palyginti su elito komandu parengtumu, siekiant įvertinti treniruojamos komandos žaideju parengtumo lygi ir numatyti treniravimo programos kryptinguma. Be to, aktualu surasti žaidejų gebejjimų tarpusavio sąveikos ypatumus, kad būtų galima taikyti optimalias individualias rengimo programas.

Tyrimo tikslas - nustatyti pusiau profesionalios merginų rankinio komandos žaidejjų parengtumą ir parengtumo rodiklių tarpusavio priklausomybès ypatumus pradedant sportini sezoną.

\section{TYRIMO METODIKA}

Tiriamosios. Buvo tiriamos pusiau profesionalios rankininkès (PPR) $(\mathrm{n}=14)$, kurios treniravosi 5 dienas per savaitę (5 kartus), o varžybu mikrociklo metu - 4 dienas (4 kartus) per savaitę, kartu žaisdamos dvejas rungtynes (iš viso 6 fizinio krūvio dienos). Rankininkių parengtumas nustatytas ivvertinant kūno masès komponentus, atletini ir technini parengtumą.
Nustatyti tokie rankininkiu parengtumo požymiai:

1. Totaliniai rodikliai ir kūno masès komponentai. Ügis, kojų ilgis, liemens ilgis nustatytas remiantis J. Skernevičiaus ir bendraautoriu aprašyta metodika (2004). Pastaruoju metu kūno masès komponentai nustatomi (Prins et al., 2008) kūno kompozicijos analizatoriumi (Body Composition Analyser Tanita BC-418MA, Japonija). Juo buvo išmatuoti kūno masès, kūno masès indekso (KMI), beriebalinès kūno masès $(\mathrm{kg})$, riebalinès masès $(\mathrm{kg}$ ir \%), skysčiu ( $\mathrm{kg})$, riebalinès masès ( $\mathrm{kg}$ ir \%), raumenu masès $(\mathrm{kg})$ rodikliai.

2. Atletinis parengtumas. Aerobine ištverme nustatyta taikant 12 minučiu bėgimo K. H. Kuperio testą (Cooper, 1968) - registruotas atstumas, nubėgtas per 12 minučių. Taikant formulę (Carling et al., 2009) netiesioginiu būdu nustatytas maksimalusis deguonies suvartojimas:

$$
\begin{aligned}
& \mathrm{VO}_{2 \max }(\mathrm{ml} / \mathrm{kg} / \mathrm{min})=[(\text { nubejgtas atstu- } \\
& \text { mas metrais }-0,3138) / 0,0278 / 1,609]
\end{aligned}
$$

Yo-Yo nutrūkstamo intensyvumo ištvermès ir atsigavimo 1 lygio testai (Bangsbo et al., 2008), susideda iš $2 \times 20$ metrų šaudyklinio bègimo kintant bègimo greičiui. Greitis reguliuojamas garso signalais. Testo garsiniai signalai reguliavo tiriamuju poilsio tarp bėgimu $(2 \times 20 \mathrm{~m})$ intervalus: 10 sekundžių - ištvermès ir 5 sekundès - atsigavimo. Galinę liniją pakanka užminti, nebūtina ją peržengti. Testas yra baigiamas, kai žaidejja du kartus iki signalo nespejja kirsti finišo linijos. Skaičiuojamas nubėgtas atstumas metrais.

Galingumas. Kojų raumenų galingumas nustatytas atliekant jègos greitumo ( $\mathrm{J}-\mathrm{G}$ iš fiksuotos padèties pritūpus ir kojas per kelius sulenkus $135^{\circ}$ kampu) ir greitumo jègos (G-J šuolius amortizuojamai pritūpus - kojos per kelius sulenktos $135^{\circ}$ kampu) - su ranku mostu ir be jo. Testuota taikant NEWTEST (Suomija) matavimo irengini. Kiekvienu atveju atlikta po tris šuoliukus nustatant J-G ir G-J su rankų mostu ir be jo - iš viso 12 šuoliuku, o registruojamas geriausias šuolis (Skurvydas, 2008).

Vikrumas tirtas keliais testais: Šešiakampio testu matuotas laikas, sugaištas šuoliuojant tris ratus už visų stačiakampio kraštinių (Brittenham, 1998); Kvadrato testu registruotas šuoliukų skaičius per 10 sekundžių (Skernevičius ir kt., 2004); Bumerango ir aštuoneto testais registruotas sugaištas bejgimo laikas tiriamajai judant su kamuoliu ir be jo dviem būdais: reglamentuotai (nesisukant aplink kūno aši), 
1 lentelè. Pusiau profesionalių rankininkių parengtumo nustatymo eiga

\begin{tabular}{|l|l|}
\hline \multicolumn{1}{|c|}{2009 m. liepos 30 d. } & \multicolumn{1}{c|}{2009 m. liepos 31 d. } \\
\hline Rytas & Rytas \\
\hline Pramankšta & Antropometrija. Kūno masès komponentai \\
\hline Metimai & Pramankšta \\
\hline Kojų raumenų galingumas & Kamuolio metimas ị toli \\
\hline Šuoliavimas kvadrate & Kuperio testas \\
\hline Vakaras & Vakaras \\
\hline Pramankšta & Pramankšta \\
\hline Galūnių judesių dažnumas & Bumerango testas \\
\hline Šešiakampio testas & Aštuoneto testas \\
\hline Kamuolio gaudymas ir perdavimas & Yo-Yo atsigavimo testas \\
\hline Yo-Yo ištvermės testas & \\
\hline
\end{tabular}

o kitu atveju nereglamentuojant judejjimo sąlygu (apibėgant stovelius) (Jahuson, 1986).

Judesiu dažnumas. Rankų ir kojų judesių dažnumas nustatytas keliais testais: rankų judesių dažnumas - pagal Eurofito testą, registruojant sugaištą laiką ir judesių skaičiu per 10 ir $60 \mathrm{~s}$; koju judesių dažnumas - perkeliant kojas i prieki, atgal, i šonus ir registruojant judesių skaičiu per 10 s (Skernevičius ir kt., 2004).

3. Techninis parengtumas. Kamuolio metimo greitis. Buvo atliekami 7 metru baudos metimai ir metimai nuo 9 metru linijos iš atremties ir pašokus. Atliekama po tris bandymus registruojant geriausią rezultatą. Testuota taikant „, Speed Sport Radar" (Amerika) matavimo irengini. Metimo greitis buvo registruojamas $\mathrm{km} / \mathrm{h}$.

Kamuolio metimo i toli testas buvo atliekamas Lietuvos kūno kultūros akademijos lengvosios atletikos manieže. Žaidèjos žengdavo tris žingsnius ir mesdavo rankinio kamuoli i tolị. Buvo atliekami trys bandymai.

Kamuolio gaudymas ir perdavimas (Garbaliauskas, 1986). Per 30 sekundžiu žaidejjas turi kuo greičiau ir tiksliau mesti kamuolị $\mathfrak{i}$ taikini, esanti ant sienos $180 \mathrm{~cm}$ aukštyje $(40 \times 40)$. Atstumas iki taikinio 3 metrai. Skaičiuojamas pataikymu skaičius.

Kamuolio varymo technika nustatyta atliekant vikrumo Aštuoneto ir Bumerango testus varant kamuolic.

4. Matematinė statistika: skaičiuoti aritmetiniai vidurkiai, standartinis nuokrypis. Ryšiams tarp rodiklių nustatyti skaičiuotas Pirsono (Pearson) koreliacijos koeficientas $r$.
Tyrimo organizavimas. Atletinis ir techninis parengtumas nustatytas $2009 \mathrm{~m}$. liepos mènesi, prieš pradedant sportini sezona. Testavimas vyko dvi dienas ryte ir vakare (1 lent.).

\section{REZULTATAI}

Kūno kompozicija. Žaidèjų vidutinis ūgis $176,3 \pm 6,1 \mathrm{~cm}$, kūno masè $69,9 \pm 9,7 \mathrm{~kg}$ (2 lent.). Aukščiausios ir sunkiausios komandos vartininkès $11,2 \mathrm{~cm}$ aukštesnès ir 19,3 kg sunkesnès už žemiausias ir mažiausiai sveriančias krašto žaidèjas. Antros (II) linijos žaidejos yra aukštesnès $2,5 \mathrm{~cm}$ už pirmos (I). Didžiausi kūno masès komponentu (poodinio riebalinio sluoksnio, aktyviosios kūno masès ir vandens kiekio) rodikliai buvo vartininkių, mažiausi - krašto žaidejjų. I ir II linijos žaidèjų kūno masès komponentai beveik nesiskyrè.

Atletinis parengtumas. Dèl nereikšmingo rodiklių skirtumo tarp skirtingų pozicijų žaidejų jie pateikiami lyginant aikštès ir vartininkų, I ir II linijos žaidèjų rodiklius.

Kuperio testas. Vidutiniškai žaidejos nubėgo $2,3 \pm 0,19 \mathrm{~km}$ (3 lent.). Aikštès žaidèjos nubègo $300 \mathrm{~m}$ daugiau nei vartininkès. II $(2,4 \pm 0,14)$ ir I $(2,36 \pm 0,18)$ linijos žaidejjos nubėgo beveik vienodai. Komandos vidutinis $\mathrm{VO}_{2 \max }$ buvo $46 \pm$ $5,8 \mathrm{ml} / \mathrm{kg} / \mathrm{min}$. Aikštès žaidèjų $(46,7 \pm 5,9)$ $\mathrm{VO}_{2 \max }$ buvo $5,7 \mathrm{ml} / \mathrm{kg} /$ min didesnis nei vartininkių $(41 \pm 3,1)$. I linijos žaidèjų $(48,6 \pm 6,5) \mathrm{VO}_{2 \max }$ buvo $3,3 \mathrm{ml} / \mathrm{kg} /$ min didesnis negu II linijos žaidejju $(45,1 \pm 5,1)$. Didžiausia $\mathrm{VO}_{2 \max }$ reikšmè buvo krašto žaidejos $(56,2 \mathrm{ml} / \mathrm{kg} / \mathrm{min})$, mažiausia pusiau krašto žaidèjos $(38,6 \mathrm{ml} / \mathrm{kg} / \mathrm{min})$. 


\begin{tabular}{|c|c|c|c|c|c|c|}
\hline \multirow[b]{2}{*}{$\begin{array}{l}\text { Pozicijos / } \\
\text { Rodikliai }\end{array}$} & \multicolumn{2}{|c|}{ Visuotiniai kūno rodikliai } & \multicolumn{4}{|c|}{ Kūno masės komponentai } \\
\hline & $\overline{\text { Ūgis, }} \mathbf{c m}$ & $\begin{array}{c}\text { Kūno } \\
\text { masė, kg }\end{array}$ & KMI & $\begin{array}{c}\text { Poodinio riebalinio } \\
\text { sluoksnio kiekis, \% ir kg }\end{array}$ & $\begin{array}{c}\text { Aktyvioji } \\
\text { kūno masė, kg }\end{array}$ & $\begin{array}{l}\text { Vandens } \\
\text { kiekis, kg }\end{array}$ \\
\hline \multirow{2}{*}{$\begin{array}{l}\text { Krašto žaidejos } \\
(\mathrm{n}=4)\end{array}$} & \multirow{2}{*}{$171,3 \pm 4,9$} & \multirow{2}{*}{$62,6 \pm 5,4$} & \multirow{2}{*}{$21,2 \pm 0,9$} & $17,2 \pm 2,2 \%$ & \multirow{2}{*}{$51,8 \pm 3,1$} & \multirow{2}{*}{$37,9 \pm 2,3$} \\
\hline & & & & $10,8 \pm 2,4 \mathrm{~kg}$ & & \\
\hline \multirow{2}{*}{$\begin{array}{l}\text { Pusiau krašto } \\
\text { žaidejjos }(n=4)\end{array}$} & \multirow{2}{*}{$177,8 \pm 5,6$} & \multirow{2}{*}{$68,6 \pm 9,2$} & \multirow{2}{*}{$21,6 \pm 1,5$} & $19,4 \pm 3,5 \%$ & \multirow{2}{*}{$55,1 \pm 5,3$} & \multirow{2}{*}{$40,3 \pm 3,9$} \\
\hline & & & & $13,5 \pm 4,1 \mathrm{~kg}$ & & \\
\hline \multirow[b]{2}{*}{ İžaidèjos $(\mathrm{n}=2)$} & \multirow[b]{2}{*}{$173 \pm 4,2$} & \multirow[b]{2}{*}{$66,5 \pm 4,7$} & \multirow[b]{2}{*}{$22,2 \pm 0,5$} & $22 \pm 1,5 \%$ & \multirow[b]{2}{*}{$51,9 \pm 2,8$} & \multirow[b]{2}{*}{$38 \pm 2,1$} \\
\hline & & & & $14,7 \pm 2,1 \mathrm{~kg}$ & & \\
\hline \multirow{2}{*}{$\begin{array}{l}\text { Linijos žaidejos } \\
(\mathrm{n}=2)\end{array}$} & \multirow{2}{*}{$179,5 \pm 3,5$} & \multirow{2}{*}{$79,4 \pm 7,4$} & \multirow{2}{*}{$24,6 \pm 1,3$} & $25,5 \pm 3,5 \%$ & \multirow{2}{*}{$59,8 \pm 8,3$} & \multirow{2}{*}{$43,7 \pm 6,1$} \\
\hline & & & & $19,7 \pm 0,9 \mathrm{~kg}$ & & \\
\hline \multirow{2}{*}{$\begin{array}{l}\text { Vartininkès } \\
(\mathrm{n}=2)\end{array}$} & \multirow{2}{*}{$182,5 \pm 4,9$} & \multirow{2}{*}{$81,9 \pm 1,2$} & \multirow{2}{*}{$24,6 \pm 1,7$} & $25,5 \pm 1,7 \%$ & \multirow{2}{*}{$61 \pm 0,5$} & \multirow{2}{*}{$44,7 \pm 0,4$} \\
\hline & & & & $20,9 \pm 1,7 \mathrm{~kg}$ & & \\
\hline \multirow{2}{*}{$\begin{array}{l}\text { I linijos žaidejos } \\
(\mathrm{n}=6)\end{array}$} & \multirow{2}{*}{$174 \pm 5,8$} & \multirow{2}{*}{$\begin{array}{c}68,2 \pm \\
10,2\end{array}$} & 224 & $19,8 \pm 4,6 \%$ & & \\
\hline & & & $22,4 \pm 1,9$ & $13,8 \pm 4,9 \mathrm{~kg}$ & $54,4 \pm 6,1$ & $39,8 \pm 4,4$ \\
\hline II linijos žaidèjos & & & & $19,6 \pm 3,2 \%$ & & \\
\hline$(n=6)$ & $176,5 \pm 6$ & $67,7 \pm 8,5$ & $21,6 \pm 1,4$ & $13,5 \pm 3,7 \mathrm{~kg}$ & $54,2 \pm 5,2$ & $39,7 \pm 3,8$ \\
\hline Aikštès žaidèjos & 1752 & $678,8-3$ & $22+17$ & $19,7 \pm 3,8 \%$ & 542,2 & 20 \\
\hline$(n=12)$ & 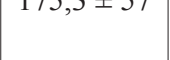 & $01,9 \pm 9$ & $22 \pm 1,1$ & $13,6 \pm 4,2 \mathrm{~kg}$ & $34,3 \pm J, 4$ & $39,0 \pm 3,9$ \\
\hline Komandos & 1762 & $600-1$ & 27 & $20,5 \pm 4,1 \%$ & $55 ? 2,2$ & 10 \\
\hline vidurkis & $1 / 0,3 \pm 0,1$ & ( & $22,4 \pm 1,0$ & $14,6 \pm 4,7 \mathrm{~kg}$ & נ, & $40,3 \pm 4$ \\
\hline
\end{tabular}

Yo-Yo nutrūkstamo intensyvumo ištvermès ir atsigavimo testai (I lygio). Atlikdamos ištvermès testą, žaidèjos vidutiniškai nubėgo $1593 \pm$ $566 \mathrm{~m}$ (3 lent.). Aikštės žaidèjos nubėgo $620 \mathrm{~m}$ daugiau nei vartininkès $(1060 \pm 594 \mathrm{~m})$. II linijos žaidejos nubègo $112 \mathrm{~m}$ daugiau nei I linijos žaidèjos (1664 $\pm 483 \mathrm{~m})$. Žaidèjų laktato koncentracija kraujyje po testo vidutiniškai buvo $10,4 \pm$ $2,8 \mathrm{mmol} / 1$. Aikštès žaidejuu laktato koncentracija kraujyje buvo $3,4 \mathrm{mmol} / 1$ didesnè nei vartininkiu $(7,6 \pm 4,5 \mathrm{mmol} / 1)$. Atlikdamos Yo-Yo atsigavimo testą, žaidejjos vidutiniškai nubègo $554 \pm 204 \mathrm{~m}$. Aikštès žaidèjos nubègo $253 \mathrm{~m}$ daugiau nei vartininkès $(320 \pm 0 \mathrm{~m})$. I ir II linijos žaidèjos nubègo beveik tiek pat $(584 \pm 220$ ir $573,3 \pm 201 \mathrm{~m})$. Žaidejjų laktato koncentracija kraujyje po atsigavimo testo buvo 3,4 mmol / 1 (vidutiniškai $-13,8 \pm$ $2,7 \mathrm{mmol} / \mathrm{l}$ ) didesnè negu po ištvermès testo. Aikštės žaidejjų laktato koncentracija kraujyje buvo $0,5 \mathrm{mmol} / 1$ mažesnè nei vartininkių. I linijos žaidèjų $(10,8 \pm 2,02 \mathrm{mmol} / \mathrm{l})$ laktato koncentracija kraujyje po ištvermès testo buvo $0,4 \mathrm{mmol} / 1$ mažesnè nei II linijos $(11,2 \pm 2,8 \mathrm{mmol} / \mathrm{l})$. Po atsigavimo testo $-1,3 \mathrm{mmol} / 1$ didesné laktato koncentracija buvo I linijos žaidèjų.

Galingumas. Atlikdamos J-G šuolius komandos žaidejos vidutiniškai pašoko $-28,2 \pm 2,9 \mathrm{~cm}$ ir $35,4 \pm 3,5 \mathrm{~cm}$ (3 lent.). I linijos žaidejos tokiu būdu pašoko $2,3 \mathrm{~cm}$ (be mosto) ir $1 \mathrm{~cm}$ (su rankų mostu) aukščiau už II linijos žaidejjas. Atlikdamos G-J šuolius, I linijos žaidejjos taip pat pašoko aukščiau - atitinkamai 3,3 ir 2,2 cm nei II linijos žaidejjos. Kojų raumenų galingumas (J-G ir G-J) geresnis buvo I linijos žaidejų nei II linijos. Atlikdamos Šešiakampio testą, galingesnès buvo II linijos žaidèjos (3 lent.), o atlikdamos Kvadrato testą galingumu pasižymèjo I linijos žaidejos. Atlikdamos galingumo testus pašokant aukštyn, galingesnès buvo I linijos žaidejjos, bet atlikdamos šuoliavimo į šonus testą (Šešiakampio) - II linijos žaidejos.

Vikrumas. Nereglamentuoto Bumerango vikrumo testo be kamuolio ir su kamuoliu rodikliai I ir II linijos žaidèjų buvo vienodi $(13,1$ ir 13,9$)$ (3 lent.). Atlikdamos reglamentuotą testą be kamuolio vikresnès buvo I linijos žaidejjos, su ka- 


\begin{tabular}{|c|c|c|c|c|c|c|c|}
\hline \multirow{4}{*}{$\begin{array}{l}3 \text { lentelè. Pusiau } \\
\text { profesionalių ran- } \\
\text { kininkių atletinio } \\
\text { ir techninio pa- } \\
\text { rengtumo rodi- } \\
\text { kliai }(\bar{x} \pm S D)\end{array}$} & \multicolumn{2}{|c|}{ Rodikliai } & $\begin{array}{c}\text { Komandos } \\
\text { vidurkis }\end{array}$ & $\begin{array}{l}\text { Aikštės } \\
\text { žaidèjos }\end{array}$ & Vartininkès & $\begin{array}{l}\text { I linijos } \\
\text { žaidèjos }\end{array}$ & $\begin{array}{l}\text { II linijos } \\
\text { žaidèjos }\end{array}$ \\
\hline & \multicolumn{2}{|c|}{ Atletinis parengtumas } & \multicolumn{5}{|c|}{ Kuperio testas } \\
\hline & \multicolumn{2}{|c|}{ Nubėgtas atstumas, km } & $2,3 \pm 0,19$ & $2,4 \pm 0,16$ & $2,1 \pm 0,35$ & $2,4 \pm 0,14$ & $2,36 \pm 0,18$ \\
\hline & \multicolumn{2}{|c|}{$\mathrm{VO}_{2 \max }, \mathrm{ml} / \mathrm{kg} / \mathrm{min}$} & $46 \pm 5,8$ & $46,7 \pm 5,9$ & $41 \pm 3,1$ & $48,6 \pm 6,5$ & $45,1 \pm 5,1$ \\
\hline & & \multirow[b]{2}{*}{ Nubėgtas atstumas, $\mathrm{m}$} & \multicolumn{5}{|c|}{ Yo-Yo testas } \\
\hline & Ištvermès & & $1593,3 \pm 566$ & $1680 \pm 533$ & $1060 \pm 594$ & $1664 \pm 483$ & $1776 \pm 636$ \\
\hline & & Laktatas, mmol / 1 & $10,4 \pm 2,8$ & $11 \pm 2,28$ & $7,6 \pm 4,5$ & $10,8 \pm 2,0$ & $11,2 \pm 2,8$ \\
\hline & \begin{tabular}{|l|l} 
Atsigavimo & $\mathrm{N}$ \\
\end{tabular} & Nubėgtas atstumas, $\mathrm{m}$ & $553,8 \pm 204$ & $573,3 \pm 198$ & $320 \pm 0$ & $584 \pm 220$ & $573,3 \pm 201$ \\
\hline & & Laktatas, mmol / 1 & $13,8 \pm 2,7$ & & $14,2 \pm 6,22$ & $14,5 \pm 0,93$ & $13,2 \pm 3,06$ \\
\hline & & & \multicolumn{5}{|c|}{ Galingumas } \\
\hline & \multirow{4}{*}{ Šuoliai } & $\mathrm{J}-\mathrm{G}$ be mosto, $\mathrm{cm}$ & $28,2 \pm 2,9$ & $28,3 \pm 3,1$ & $27,7 \pm 2,2$ & $29,7 \pm 3$ & $27,4 \pm 2,7$ \\
\hline & & J-G su mostu, cm & $35,4 \pm 3,5$ & $35,8 \pm 3,7$ & $33,2 \pm 0,8$ & $36,6 \pm 4,3$ & $35,1 \pm 3,1$ \\
\hline & & G-J be mosto, cm & $30,2 \pm 2,7$ & $30,5 \pm 2,8$ & $28,6 \pm 1,3$ & $32,4 \pm 2,8$ & $29,1 \pm 1,9$ \\
\hline & & G-J su mostu, cm & $36,6 \pm 3,4$ & $36,9 \pm 3,6$ & $34,5 \pm 1,8$ & $38,2 \pm 4,3$ & $36 \pm 2,7$ \\
\hline & \multirow{2}{*}{ Testai } & Šešiakampio testas, $\mathrm{s}$ & $15,8 \pm 1,9$ & $15,8 \pm 2$ & $15,7 \pm 0,6$ & $16,1 \pm 2,4$ & $15,5 \pm 1,7$ \\
\hline & & Kvadrato testas, šuoliai & $29 \pm 3,6$ & $30 \pm 2,8$ & $23 \pm 1,4$ & $31,2 \pm 3,3$ & $29,1 \pm 2,3$ \\
\hline & \multicolumn{2}{|l|}{ Vikrumo testas } & \\
\hline & \multirow[b]{2}{*}{ Be kamuolio, s } & Nereglamentuota & \multicolumn{5}{|c|}{\begin{tabular}{l|l|l}
0,4 & $14,9 \pm 1,2$ & 13,
\end{tabular}} \\
\hline & & $\begin{array}{l}\text { Nesisukant apie } \\
\text { kūno vertikalią aši }\end{array}$ & $15,4 \pm 0,7$ & $15,1 \pm 0,5$ & $16,6 \pm 0,3$ & $15 \pm 0,6$ & $15,2 \pm 0,5$ \\
\hline & \multirow[b]{2}{*}{ Su kamuoliu, s } & Nereglamentuota & $14,1 \pm 0,8$ & $13,9 \pm 0,6$ & $15,6 \pm 0,3$ & $13,9 \pm 0,5$ & $13,9 \pm 0,6$ \\
\hline & & $\begin{array}{l}\text { Nesisukant apie } \\
\text { kūno vertikalią aši }\end{array}$ & $17,2 \pm 1,3$ & $17 \pm 1,3$ & $18,4 \pm 0,5$ & $17,2 \pm 1,2$ & $16,8 \pm 1,4$ \\
\hline & & & & & tuoneto testa & & \\
\hline & & Nereglamentuota & $15 \pm 0,8$ & $15 \pm 0,86$ & $15,3 \pm 0,79$ & $15 \pm 0,85$ & $14,9 \pm 0,9$ \\
\hline & Be kamuolio, s & $\begin{array}{l}\text { Nesisukant apie } \\
\text { kūno vertikalią aši }\end{array}$ & $17,2 \pm 0,9$ & $17 \pm 0,88$ & $18 \pm 0,82$ & $16,7 \pm 0,89$ & $17,3 \pm 0,93$ \\
\hline & & Nereglamentuota & $16,5 \pm 0,8$ & $16,5 \pm 0,8$ & $16,5 \pm 1$ & $16,7 \pm 0,5$ & $16,3 \pm 0,9$ \\
\hline & Su kamuoliu, s & $\begin{array}{l}\text { Nesisukant apie } \\
\text { kūno vertikalią aši }\end{array}$ & $19,9 \pm 1,4$ & $19,6 \pm 1,2$ & $21,6 \pm 1,5$ & $19,4 \pm 1,5$ & $19,8 \pm 0,7$ \\
\hline & & & & Rank & judesių dažı & Iumas & \\
\hline & Kairè & & $13,2 \pm 1,16$ & $13,1 \pm 1,22$ & $13,9 \pm 0,42$ & $14 \pm 1,44$ & $12,5 \pm 0,67$ \\
\hline & Dešinè & & $11,7 \pm 0,54$ & $11,6 \pm 0,54$ & $12,2 \pm 0,04$ & $11,9 \pm 0,44$ & $11,5 \pm 0,64$ \\
\hline & $10 \mathrm{~s}$ testas & & $72,1 \pm 7,4$ & $73,4 \pm 7,2$ & $64,5 \pm 0,7$ & $68,7 \pm 3,5$ & $80 \pm 5,8$ \\
\hline & $60 \mathrm{~s}$ testas & & $446,3 \pm 45,6$ & $455,8 \pm 42$ & $389,5 \pm 12$ & $440,4 \pm 24,7$ & $477,2 \pm 54,2$ \\
\hline & & & & Kojų & judesių dažn & umas & \\
\hline & Kojas keliant 90 & $0^{0} \mathrm{kampu}$ & $13,4 \pm 1,34$ & $13,5 \pm 1,38$ & $13 \pm 1,41$ & $13,4 \pm 0,84$ & $13,6 \pm 1,87$ \\
\hline & Perkeliant kojas & $\mathrm{s}$ i priekị ir atgal & $15,2 \pm 1,58$ & $15,2 \pm 1,63$ & $15,3 \pm 1,77$ & $15,7 \pm 1,05$ & $14,9 \pm 2,13$ \\
\hline & Perkeliant kojas & s į šonus & $10,2 \pm 1,12$ & $10,3 \pm 1,16$ & $9,5 \pm 0,71$ & $10,6 \pm 1,24$ & $10,1 \pm 1,17$ \\
\hline & Techninis pareı & engtumas & & & Metimai & & \\
\hline & $7 \mathrm{~m}$ baudos met & timai, $\mathrm{km} / \mathrm{h}$ & $66,1 \pm 6,4$ & $67,6 \pm 5,7$ & $57,5 \pm 2,1$ & $67,6 \pm 4,5$ & $67,6 \pm 7,1$ \\
\hline & Iš atremtis, $\mathrm{km} /$ & & $70,4 \pm 6,4$ & $71,4 \pm 6,3$ & $64 \pm 0$ & $70,4 \pm 5,5$ & $72,1 \pm 7,2$ \\
\hline & Pašokus, km / h & & $71,9 \pm 7,4$ & $73,6 \pm 6,6$ & $62 \pm 1,4$ & $72,2 \pm 6,5$ & $74,6 \pm 7$ \\
\hline & Kamuolio metin & mas i toli, $\mathrm{m}$ & $31,8 \pm 3,4$ & $32,1 \pm 3,6$ & $30,5 \pm 2,1$ & $30,9 \pm 2,7$ & $33,3 \pm 4$ \\
\hline & Kamuolio metin & mas i kvadratą, kartai & $18,2 \pm 3$ & $18,1 \pm 3,1$ & $19 \pm 2,8$ & $18,2 \pm 3,6$ & $18 \pm 2,9$ \\
\hline
\end{tabular}

muoliu - II linijos. Atlikdamos nereglamentuotą Aštuoneto testą tiek su kamuoliu, tiek be jo, greitesnès buvo II linijos žaidejjos. Atlikdamos ši testą reglamentuotai, I linijos žaidèjos buvo greitesnès nei II linijos.

Judesiu dažnumas. Rankų judesių dažnumas II linijos žaidejjų buvo geresnis nei I linijos 2,5 s (kaire) ir 0,5 s (dešine) (3 lent.). Kairès rankos judesių dažnumas buvo blogesnis nei dešinès $1,5 \mathrm{~s}$ (nebuvo nè vienos kairiarankès). Kojų judesių daž- numas perkeliant kojas i priekí, atgal $(0,8$ karto) ir i šonus $(0,5$ karto) buvo geresnis I linijos žaidejjų, tačiau kojas perkeliant $90^{\circ} \mathrm{kampu}$ - geresnis judesių dažnumas buvo II linijos žaidèjų ( 0,2 karto). Žaidejos i prieki ir atgal judejo 5 kartais geriau nei i šonus.

Techninis parengtumas. Aikštès žaidejų rezultatai metant kamuolį buvo geresni nei vartininkių (3 lent.). I ir II linijos žaidejos 7 metrų baudinius metè tokiu pat greičiu $(67,6 \mathrm{~km} / \mathrm{h})$ (3 lent.). 
Iš atremties $(1,7 \mathrm{~km} / \mathrm{h})$ ir pašokus $(2,4 \mathrm{~km} / \mathrm{h})$ geresni rezultatai II linijos žaidejjų. I tolị aikštès žaidèjos kamuoli numetè $1,6 \mathrm{~m}$ toliau $(32,1 \mathrm{~m})$ nei vartininkès $(30,5 \mathrm{~m})$. II linijos žaidejjos kamuoli numetė 2,4 m toliau. Kamuoli i kvadrata geriau mètè vartininkès (19 kartų) nei aikštès žaidejos (18,1 kartu). I ir II linijos žaidèjų rezultatai beveik nesiskyre (18,2 ir 18). Kamuolio varymo technika atliekant Bumerango nereglamentuotą testą buvo geresnè aikštės žaidèjų $(13,9 \pm 0,6)$ nei vartininkių $(15,6 \pm 0,3)$. I ir II linijos žaidejų rezultatai buvo vienodi $(13,9$ s). Nesisukdamos aplink savo aši greičiau kamuolị varè aikštės žaidèjos $(17 \pm 1,3)$ nei vartininkès $(18,4 \pm 0,5)$. II linijos žaidèjos $(16,8 \pm 1,4)$ buvo greitesnès nei I linijos $(17,2 \pm$ $1,2)$.

\section{REZULTATŲ APTARIMAS}

Kūno kompozicija. Rungtynių sèkmę daugiausia lemia rankininkių kūno sudèjimas (ūgis, kūno mase ir riebalų bei raumenu kiekis) (Bayios et al., 2006; Hasan et al., 2007). Lyginant kūno sudejjimo rodiklius su Azijos šaliu ir Graikijos rankininkių (Bayios et al., 2006; Hasan et al., 2007) galima teigti, kad tirtos rankininkès turètu pranašumo rungtyniaudamos, tačiau rungtyniaujant su Norvegijos rankininkèmis tai būtu trūkumas (Ronglan et al., 2006).

Tirtų rankininkių ūgis, kūno masė ir aktyvioji kūno masè susijusi su galingumo rodikliais (šuolio be ranku mosto ir su juo $(\mathrm{r}=0,40-0,60))$ (4 lent.). Kaip teigia G. Ziv ir R. Lidor (2009), aukštesnès ir didesnès kūno masès, ypač aktyviosios kūno masès, rankininkai turi didesnę galimybę laimèti. Tirtų rankininkių kojų raumenų galingumą lèmé didesnè aktyvioji kūno masé $(\mathrm{r}=0,50)$. Vadinasi, parengiamuoju laikotarpiu rekomenduotina didinti rankininkiu aktyviaja kūno masę ir ypač stiprinti koju raumenu jèga (Gorostiaga et al., 2005).

Aerobinis ir anaerobinis pajėgumas. Norint visų rungtynių metu išlaikyti didelę rungtyniavimo sparta - būtinas geras aerobinis ir anaerobinis organizmo parengtumas (Cardinale, 2000; Hasan et al., 2007). C. Manchado ir P. Platen (2008) teigia, kad per rungtynes rankininkiu MDS rodikliai siekia 53,1 $\pm 4,8 \mathrm{ml} / \mathrm{kg} / \mathrm{min}$. Tirtų rankininkiu Kuperio testo metu MDS buvo blogesnis (46 \pm $5,8 \mathrm{ml} / \mathrm{kg} / \mathrm{min}$ ). Tirtos rankininkès Kuperio testo metu vidutiniškai nubėgo $200 \mathrm{~m}$ mažiau nei Lenkijos rankininkès (Jadach, Cieplinski 2008), ir MDS rodikliai buvo dviem $\mathrm{ml} / \mathrm{kg} / \mathrm{min}$ blo- gesni nei Lenkijos rankininkių. Yo-Yo nutrūkstamo intensyvumo ištvermès ir atsigavimo testai (I lygio) yra svarbūs ir reikšmingi (jie rodo žaidejuc funkcini pajègumą) (Bangsbo et al., 2008), tačiau tokių duomenų nepavyko rasti. Atliekant Yo-Yo nutrūkstamo intensyvumo ištvermès ir atsigavimo testus, laktato koncentracija kraujyje buvo 10,4 ir 13,8 mmol / 1 atitinkamai. F. Rannou su bendraautoriais (2001) teigia, kad per rungtynes laktato kraujyje susikaupia nuo 14 iki 15,3 mmol / 1 . Taigi taikyti ištvermès testai padeda nustatyti rankininkiu funkcines galias, kartu yra labai tinkama priemonè lavinti ištvermę. Parengiamuoju laikotarpiu rekomenduotina lavinti ištvermę - taip teigia E. Gorostiaga su bendraautoriais (2005). Šiuo laikotarpiu taikytini ir Kuperio testai, lavinantys aerobinę ištvermę, Yo-Yo abiejų tipų testai, padedantys gerinti specifinę ištvermę. Tai leistu pagerinti organizmo funkcines galias ir padidetu galimybė išlaikyti dideli žaidimo intensyvumą per visas rungtynes.

Kojų raumenų galingumo rodikliai. Tirtų žaideju kojų raumenų galingumas (jègos greitumo šuolio be ranku mosto) geresnis (pašoko $2 \mathrm{~cm}$ aukščiau) nei Pekino olimpiniu žaidyniu čempionių - Norvegijos rinktinès žaidèju (28,2 \pm $3,4)$. Pažymėtinas ir geresnis atskiru žaidejjų kojų raumenu galingumas: aukščiausiai Norvegijos rankininkè pašoko $32,9 \mathrm{~cm}$, tiriamos komandos rankininkè $(33,6 \mathrm{~cm})$ pašoko $0,7 \mathrm{~cm}$ aukščiau. Didelio meistriškumo komandų rezultatams turi ittakos visi rodikliai (Gorostiaga et al., 2005; Oxyzoglou et al., 2008), taigi dèl geresniu jègos greitumo rodiklių testuotos rankininkès turètų didesnę galimybę laimèti prieš norveges.

Rankininkių Kvadrato testo rezultatai yra geri, vertinant juos B. Johnson ir J. Nelson (1986) vertinimo skale. Geresni rezultatai buvo I linijos žaidèjų. Vikrumas vienas iš svarbiausių gebẻjimu, būdingų I linijos žaidèjams tiek ginantis, tiek atakuojant vartus (Arslanagicis, 1997; Oxyzoglou, 2008). Rungtyniavimo metu žaidèjoms tenka daug kartų keisti judejjimo krypti. Tai atlikti geriau geba didesnio galingumo žaidejos, nes vikrumą lemia kojų raumenų jègos ir greitumo ryšys (Carling et al., 2009). Galima sutikti su E. Gorostiaga ir bendraautoriu (2005) teiginiais, kad jègos, kaip ir ištvermès, lavinimui parengiamuoju laikotarpiu reikia skirti daug dèmesio. Žaidejos turi būti pasirengusios atlikti vikrumo reikalaujančius veiksmus visu rungtyniu metu.

Judesių dažnumas. Nors nèra sudarytos rankininkių rankų judesių dažnumo vertinimo skalès, 
4 lentelè. Pusiau profesionalių rankininkių fizinio išsivystymo, atletinio ir techninio parengtumo rodiklių ryšys

\begin{tabular}{|c|c|c|c|c|c|c|c|c|c|c|c|c|c|c|c|c|c|c|c|c|}
\hline & 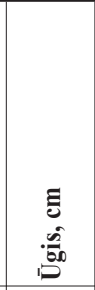 & 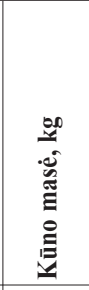 & 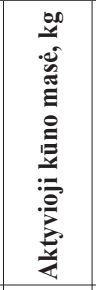 & $\begin{array}{l}\stackrel{\Xi}{0} \\
\stackrel{0}{E} \\
\stackrel{0}{0} \\
\stackrel{0}{0}\end{array}$ & 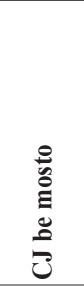 & 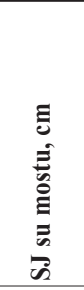 & 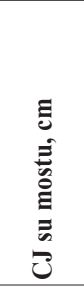 & 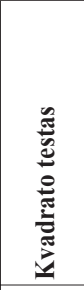 & 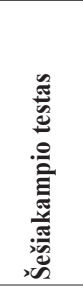 & 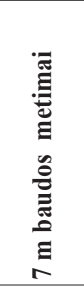 & 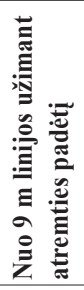 & 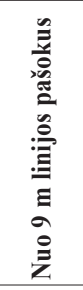 & 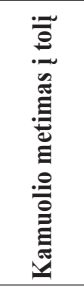 & 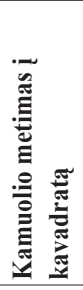 & 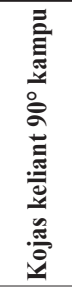 & 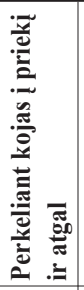 & 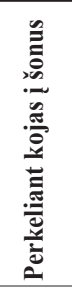 & 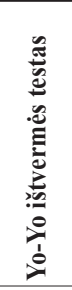 & 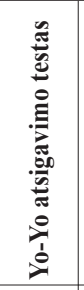 & 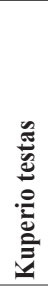 \\
\hline & 1 & 2 & 3 & 4 & 5 & 6 & 7 & 8 & 9 & 10 & 11 & 12 & 13 & 14 & 15 & 16 & 17 & 18 & 19 & 20 \\
\hline 1 & 1 & & & & & & & & & & & & & & & & & & & \\
\hline 2 & 0,89 & 1 & & & & & & & & & & & & & & & & & & \\
\hline 3 & 0,90 & 0,96 & 1 & & & & & & & & & & & & & & & & & \\
\hline 4 & 0,56 & 0,50 & 0,50 & 1 & & & & & & & & & & & & & & & & \\
\hline 5 & 0,60 & 0,41 & 0,40 & 0,89 & 1 & & & & & & & & & & & & & & & \\
\hline 6 & 0,37 & 0,28 & 0,29 & 0,91 & 0,82 & 1 & & & & & & & & & & & & & & \\
\hline 7 & 0,49 & 0,33 & 0,35 & 0,90 & 0,92 & 0,95 & 1 & & & & & & & & & & & & & \\
\hline 8 & 0,07 & $-0,02$ & $-0,15$ & 0,27 & 0,51 & 0,31 & 0,41 & 1 & & & & & & & & & & & & \\
\hline 9 & 0,52 & 0,41 & 0,48 & $-0,01$ & 0,00 & $-0,01$ & 0,00 & $-0,33$ & 1 & & & & & & & & & & & \\
\hline 10 & $-0,14$ & $-0,16$ & $-0,21$ & $-0,13$ & $-0,02$ & 0,09 & 0,04 & 0,32 & $-0,02$ & 1 & & & & & & & & & & \\
\hline 11 & 0,00 & 0,02 & $-0,07$ & $-0,06$ & $-0,09$ & 0,08 & $-0,03$ & 0,19 & 0,10 & 0,84 & 1 & & & & & & & & & \\
\hline 12 & $-0,09$ & $-0,04$ & $-0,18$ & $-0,25$ & $-0,20$ & $-0,13$ & $-0,22$ & 0,34 & 0,09 & 0,79 & 0,93 & 1 & & & & & & & & \\
\hline 13 & $-0,17$ & $-0,13$ & $-0,06$ & $-0,15$ & $-0,30$ & 0,07 & $-0,06$ & $-0,11$ & 0,17 & 0,75 & 0,78 & 0,61 & 1 & & & & & & & \\
\hline 14 & $-0,20$ & $-0,09$ & $-0,18$ & $-0,12$ & $-0,19$ & $-0,03$ & $-0,06$ & 0,14 & 0,05 & 0,09 & 0,22 & 0,24 & 0,39 & 1 & & & & & & \\
\hline 15 & 0,38 & 0,36 & 0,42 & 0,55 & 0,37 & 0,59 & 0,56 & 0,20 & 0,00 & $-0,22$ & $-0,10$ & $-0,22$ & 0,25 & 0,07 & 1 & & & & & \\
\hline 16 & 0,46 & 0,40 & 0,37 & 0,54 & 0,50 & 0,44 & 0,43 & 0,18 & $-0,27$ & $-0,04$ & 0,10 & $-0,07$ & $-0,08$ & $-0,10$ & 0,44 & 1 & & & & \\
\hline 17 & 0,18 & 0,08 & 0,07 & 0,20 & 0,19 & 0,16 & 0,08 & 0,13 & $-0,13$ & 0,27 & 0,39 & 0,31 & 0,13 & $-0,38$ & 0,07 & 0,70 & 1 & & & \\
\hline 18 & $-0,03$ & 0,00 & $-0,07$ & 0,52 & 0,51 & 0,55 & 0,53 & 0,33 & $-0,66$ & 0,10 & $-0,03$ & $-0,19$ & $-0,17$ & $-0,05$ & 0,18 & 0,65 & 0,33 & 1 & & \\
\hline 19 & $-0,03$ & $-0,19$ & $-0,19$ & 0,47 & 0,57 & 0,48 & 0,54 & 0,53 & $-0,46$ & $-0,26$ & $-0,34$ & $-0,38$ & $-0,41$ & 0,09 & 0,43 & 0,46 & 0,13 & 0,66 & 1 & \\
\hline 20 & 0,07 & 0,00 & $-0,01$ & 0,42 & 0,46 & 0,40 & 0,44 & 0,25 & $-0,61$ & $-0,15$ & $-0,21$ & $-0,35$ & $-0,34$ & $-0,20$ & 0,33 & 0,58 & 0,15 & 0,85 & 0,73 & 1 \\
\hline
\end{tabular}

gauti rezultatai yra prasti vertinant juos Eurofito vertinimo skale. Pagerinus rankų judesių dažnumą atsirastų galimybė perimti daugiau kamuolių, daugiau blokuoti varžovių metimus (Taborsky, 2001). Žaidžiant rankini gynybos metu labai svarbus judejjimas i šonus (Oxyzoglou, 2008). Tirtos žaidejjos blogiau judèjo i šonus negu i priekị ir atgal. Galètume daryti prielaidą, kad dèl nepakankamai išlavinto judejjimo žaidèjos klysta rungtyniaudamos (kai daugiau judama i šonus). Nustatyti rankininkių kojų judesių dažnumo ir jègos greitumo bei greitumo jègos rodiklių glaudūs koreliaciniai ryšiai $(r=0,55$ ir 0,59$)$ (4 lent.) nusako rankininkių treniravimo programos turinį ir pobūdi, akcentuojant galingumo pratimus ir ypač kojų judesių dažnumą judant $\mathfrak{i}$ šonus. Be to, 10 ir $60 \mathrm{~s}$ testu rezultatų kaita leidžia spręsti apie nervų sistemos veiklą, kuri kiekvienos žaidejjos buvo individuali. Individualumai leidžia žaidejjoms parinkti žaidimo funkcijas ir treneriams numatyti žaidimo strategiją, norint kuo geriau ir stabiliau žaisti per visas rungtynes.

Metimai. Vienas iš svarbiausių veiksmų žaidžiant rankini yra kamuolio metimas į vartus (Gorostiaga et al., 2005). Kamuolio metimo grei- tis ir tikslumas daugiausia lemia pelnant ivvarti (Muijtjens et al., 1991; Wagner, Muller, 2008). Didžiausias koreliacinis ryšys nustatytas tarp metimu iš atremties $(r=0,93)$ ir pašokus. Tarp kamuolio metimo greičio ir kamuolio metimo i toli rezultatu nustatytas glaudus koreliacinis ryšys $(r=0,78)$ (4 lent.). Lenkijos rinktinès žaidejos (Jadach, Cieplinski, 2008) kamuolị i tolị numeta $(37,6 \mathrm{~m})$ šešiais metrais toliau nei tirtos rankininkès $(31,8 \mathrm{~m})$. Vadinasi, reikètu parinkti tokias žaidimo kombinacijas, kad žaidejos mestų $\mathfrak{i}$ vartus isibėgejjusios - taip jos galètų išnaudoti kūno masès ir judejimo greičio privalumus ir padidintu kamuolio metimo į vartus greiti. Rekomenduotina tobulinti ir metimus iš atremties, veiksmingus dèl netikètumo, bet tada būtina stiprinti kojų, liemens ir nugaros raumenis (Gorostiaga et al., 2005; Wagner, Muller, 2008).

\section{IŠVADOS}

Nustatyti pusiau profesionalių vidutinio meistriškumo rankininkių parengtumo rodikliai, jų ryšys turi teorinę ir praktinę reikšmę apibūdinant žaidejjų parengtumo lygi, ir tai sudaro prielaidas 
parengti parengiamojo laikotarpio treniravimo programa.

Remiantis C. Carling ir bendraautorių (2009) teiginiais, judamieji gebėjimai tarpusavyje nèra priklausomi, tačiau visi kartu labai reikšmingi. Parengiamuoju laikotarpiu rekomenduotina lavinti rankininkių ištvermę, jèga, didinant jų aktyviają kūno masę, dèl kurios pagerètų kojų raumenų galingumas; gerinti rankų bei kojų judesių dažnumą. Tai labai svarūs rodikliai atliekant gynybos ir puolimo veiksmus.

Tik tolesni pusiau profesionalių rankininkių parengtumo rodiklių tyrimai leistų nustatyti taikytos treniravimo programos poveiki, optimizuoti jų rengimą.

\section{LITERATŪRA}

Arslanagicis, A. (1997). Rukomet, prirucnik za trenere, vratare $i$ igrace. Cakovec.

Bangsbo, J., Laia, M., Krustrup, P. (2008). The Yo-Yo Intermittent Recovery Test. A Useful Tool for Evaluation of Physical Performance in Intermittent Sports. Sports Medicine, 38 (1), 37-51.

Bayios, I., Bergeles, N., Apostolidis, N., Noutsos, K., Koskolou, M. (2006). Anthropometric, body composition and somatotype differences of Greek elite female basketball, volleyball and handball players. Journal of Sports Medicine and Physical Fitness, 46 (2), 271-280.

Brittenham, G. (1996). Complete Conditioning for Basketball. USA: Human Kinetics.

Cardinale, M. (2000). Handball Performance: Physiological \& Practical Approach for the Training Metabolic Aspects [interantyvus]. 2000, rugsèjis [žiūrèta 2007-1022]. Prieiga internetu: <http://coachesinfo.com/category/ team handball/176/>

Carling, C., Reilly, T., Wiliams, M. (2009). Performance Assessment for Field Sports: Physiological and Match National Assessment in Practice. London and New York: Routledge.

Cooper, K. H. (1968). A means of assessing maximal oxygen intake correlating between field and treadmill running. Journal of the American Medical Association, 203, 201-204.

Garbaliauskas, Č. (1986). Testai rankinio praktikoje. Vilnius: Respublikinis sporto metodikos kabinetas.

Gorostiaga, E., Granados, C., Ibanez, J., Izquirdo, M. (2005). Differences in physical fitness and throwing velocity among elite and amateur male handball players. International Journal Sports Medicine, 26, 225-232.

Grünanger, H., König, H. (2005). $5^{\text {th }}$ European Championship for Women's 17 Vienna 2005 qualitative trend analysis [interaktyvus]. 2005, rugpjūtis [žiūrèta 2007 09-23]. Prieiga internetu: <http://home.eurohandball. com/ehf files/specificHBI/ECh Analyses/2005/AUT/4/ Trend $\%$ 20Analyse.pdf $>$

Hasan, A., Reilly, N., Cable, N., Ramadan, J. (2007). Anthropometric profiles of elite Asian female handball players. Journal of Sports Medicine and Physical Fitness, 47 (2), 197-202

Hatzimanouil, D., Oxizoglou, N., Hatzimanouil, A., Pantos, P., Rizos, S. (2005). Anthropometric characteristics of elite athletes in team sports. Inquiries in Sport \& Physical Education, 3, 2, 131-140.

Jadach, A., Ciepliński, J. (2008). Level of physical preparation and its influence on selection of game concepts for the Polish national handball female team. Polish Journal of Sport \& Tourism, 15, 17-22.

Johnson, B. L. (1986). Practical Measurements for Evalu- ation in Physical Education. United States of America. Loftin, M., Anderson, P., Lytton, L., Pittman, P., Warren, B. (1996). Heart rate response during handball singles match-play and selected physical fitness components of experienced male handball players. Journal of Sports Medicine and Physical Fitness, 36 (2), 95-99.

Manchado, C., Platen, P. (2008). Motion Analysis and Physiological Demands in International Women's Team Handball: 14th annual ECSS Congress Estoril. Portugal, July 9-12, 2009.

Muijtjens, A., Joris, H., Kemper, H., Ingen Schenau Van, G. (1991). Throwing practice with different ball weights: Effects on throwing velocity and muscle strength in female handball players. Sports Medicine, Training and Rehabilitation, 2, 103-113.

Oxyzoglou, N., Hatzimanouil, D., Kanioglou, A., Papadopoulou, Z. (2008). Profile of Elite Handball Athletes by Playing Position [interaktyvus]. 2008, rugpjūtis [žiūrèta 2009-01-12]. Prieiga internetu: <http://ejmas.com/ pt/2008pt/ptart_hatzimanouil_0806.html>

Prins, M., Hawkesworth, S., Wright, A. et al. (2008). Use of bioelectrical impedance analysis to assess body composition in rural Gambian children. European Journal of Clinical Nutrition, 62, 9, 1065-1074.

Rannou, F., Prioux, J., Zoufal, H., Grates-Delamarche, A., Delamarche, P. (2001). Physiological profile of handball players. Journal of Sports Medicine and Physical Fitness, 41, 3, 349-353.

Ronglan, T., Raasted, T., Borgesen, A. (2006). Neuromuscular fatigue and recovery in elite female handball players. Scandinavian Journal of Medicine Science in Sports, 16, 267-273.

Skernevičius, J., Raslanas, A., Dadelienė, R. (2004). Sporto mokslo tyrimu metodologija. Vilnius: Lietuvos sporto informacijos centras.

Skurvydas, A. (2008). Judesiu mokslas: raumenys, valdymas, mokymas, reabilitavimas, sveikatinimas, treniravimas. Kaunas: LKKA.

Taborsky, F. (2001). Game performance in Handball. Periodical for Coaches, Referees and Lecturers, 2 (12), 23-26.

Wagner, H., Muller, E. (2008). The effects of differential and variable training on the quality parameters of a handball throw. Sports Biomechanics, 7, 1, 54-71.

Wallace, M., Cardinale, M. (1997). Conditioning for team handball. Journal of Strength and Conditioning Research, $12,7-12$.

Ziv, G., Lidor, R. (2009). Physical characteristics, physiological attributes, and on-court performances of handball players: A review. European Journal of Sport Science, 9 (6), 375-386. 


\title{
FITNESS PROFILE IN SEMI-PROFESSIONAL WOMEN HANDBALL AT THE BEGINNING OF SEASON
}

\author{
Gintarė Onusaitytė, Antanas Skarbalius \\ Lithuanian Academy of Physical Education, Kaunas, Lithuania
}

\begin{abstract}
The purpose of this study was to estimate fitness and interaction between indices in semi-professional women handball at the beginning of season. Kinanthropometry data, physical fitness [endurance was evaluated using a 12-minute Cooper's test and Yo-Yo intermittent endurance and recovery (1 level) tests; vertical jump, counter movement jump; agility; movement frequency], technical fitness (throwing velocity, long-distance handball throw, passing and catching the ball, dribbling) were obtained.

The hight of players were $176.3 \pm 6.1 \mathrm{~cm}$, body mass $69.9 \pm 9.7 \mathrm{~kg}$ on average. During Cooper's test the players ran $2.3 \pm 0.19$ kilometres, and thus we estimated indirect (according Cooper's test results) $\mathrm{VO}_{2 \max }$ - the highest was $56.2 \mathrm{ml} / \mathrm{kg} / \mathrm{min}$, the lowest $-38.6 \mathrm{ml} / \mathrm{kg} / \mathrm{min}$. Results of Yo-Yo intermittent endurance and recovery tests (1 level) were $1593 \pm 566$ ir $554 \pm 204$ meters on average, and lactate amount was $10.4 \pm 2.8$ and $13.8 \pm 2.7 \mathrm{mmol} / 1$ respectively. The players performed squat jumps $-30.2 \pm 2.7$ and vertical jumps $-36.6 \pm 3.4 \mathrm{~cm}$ on average, and counter movement jumps respectively $-28.2 \pm 2,9$ and $35.4 \pm 3.5 \mathrm{~cm}$. The highest throwing velocity was found in jump throw $(71.9 \pm 7.4 \mathrm{~km} / \mathrm{h})$, the lowest — in throw on the spot $(7$ meters line $-66.1 \pm 6.4 \mathrm{~km} / \mathrm{h}$ ).

Significant correlations were found between: body mass and power of leg muscles $(r=0,40-0,60)$, power of leg muscles and movement frequency $(\mathrm{r}=0.55-0.59)$. Also we found significant correlations between throwing velocity and long-distance handball throw $(\mathrm{r}=0.78)$. Information on training-related issues, such as anthropometric measurements, physiological attributes and fitness of handball players can be utilized effectively in handball programmes. C. Carling et al. (2009) examined those abilities (sprinting, agility and vertical jumping) as independent but important locomotors skills. Training of endurance, strength, movement frequency should be implemented in team handball training programmes.
\end{abstract}

Keywords: women handball, physical and technical fitness, testing.

Gauta 2010 m. kovo 30 d.

Received on March 30, 2010

Lietuvos kūno kultūros akademija

(Lithuanian Academy of Physical Education)

Sporto g. 6, LT-44221 Kaunas

Lietuva (Lithuania)

Tel +370 37209144

E-mail a.skarbalius@1kka.1t 